\title{
\begin{tabular}{lllllllllllllllll} 
& N E W & I & $S$ & $S$ & $U$ & $E$ & $S$, & $N$ & $E$ & W & P R O J E C & T & $S$ \\
\hline
\end{tabular}
}

Ethnologia Polona, vol. 40:2019, 247-276

PL ISSN 0137-4079, The Article DOI: 10.23858/EthP40.2019.013

\section{POLISH ROMA MIGRATIONS - TRANSNATIONALISM AND IDENTITY IN ANTHROPOLOGICAL PERSPECTIVE}

\author{
KAMILA FIAŁKOWSKA \\ CENTRE OF MIGRATION RESEARCH, UNIVERSITY OF WARSAW \\ MICHAE P. GARAPICH \\ CENTRE OF MIGRATION RESEARCH, UNIVERSITY OF WARSAW \\ ELŻBIETA MIRGA-WÓJTOWICZ \\ CENTRE OF MIGRATION RESEARCH, UNIVERSITY OF WARSAW \\ PEDAGOGICAL UNIVERSITY IN KRAKOW
}

Until recently, the migration of Polish Roma has not been a subject of an academic inquiry. This article aim is to shed light on some issues related to transnational living and identity of Polish Roma in anthropological perspective ${ }^{1}$. The findings of our research suggest that Roma migrations from Poland are not categorically different from non-Roma population and in fact are integral and socially connected part of history of migrations from Poland on local and national level, determined by same processes of structural forces rendering people to seek opportunities abroad. Our study has demonstrated how crucial and important is for Polish Roma their connection to Poland - on social, personal, cultural and economic level. This calls for a more careful and nuanced approach in future research to Polish Roma identity seen in relational terms. Finally, our article calls for a need to a more ethically informed research with the Roma whose Polish identity needs to be recognized in its own right, in particular in migratory context. This means also few policy recommendations that we offer at the end of the article.

Do niedawna migracja polskich Romów nie była przedmiotem badań naukowych, stąd też celem tego artykułu jest rzucenie światła na niektóre kwestie związane z ich transnarodowym życiem i tożsamością w perspektywie antropologicznej. Wyniki naszych badań sugerują, że migracje Romów z Polski nie różnią się zasadniczo od migracji ludności nieromskiej i w rzeczywistości stanowią integralną i społecznie powiązaną część historii migracji z Polski na poziomie lokalnym i krajowym, zdeterminowaną przez te same warunki strukturalne, które motywują ludzi do wyjazdów za granicę. Nasze badanie

I Founding source: Polonez NCN "Continuity or change - Anthropological analysis of Polish Roma migration paths to Great Britain", grant No. 2015/19/P/HS6/04I25. The project has received funding from the European Union's Horizon 2020 research and innovation programme under the Marie Skłodowska-Curie grant agreement No. 665778. 
pokazało, jak ważna dla polskich Romów jest ich łączność z Polską - na poziomie społecznym, osobistym, kulturowym i gospodarczym. Wymaga to ostrożniejszego i bardziej zniuansowanego podejścia do przyszłych badań nad polską tożsamością Romów. Wreszcie, nasz artykuł wzywa do potrzeby bardziej świadomych etycznie badań z udziałem Romów, których polska tożsamość nie może być kwestionowana, w szczególności w kontekście migracji. Oznacza to również kilka rekomendacji w tym obszarze, które proponujemy na końcu artykułu.

Keywords: Roma migration, transnationalism, identity, Polish Roma, ethics

\section{INTRODUCTION}

This article presents some findings from a research project which explored international migration of Polish Roma since 1989. For many observers it may come as a surprise that a group stereotypically associated with mobility and nomadic lifestyle has never been the subject of interest from Polish migration scholars. Also, despite its rich traditions, the Polish Romani studies never looked at the issue. We explore the reasons behind that academic discursive silencing of Roma mobility elsewhere (Fiałkowska, Garapich, Mirga-Wójtowicz 20I8) aiming at bringing together two strands of scholarship together - migration studies and Romani studies. This article continues this attempt but through a more empirically and ethnographically grounded argument on the need to frame Polish Roma migration culture, their agency and structural determinants governing their mobility as part of broader processes of migration from Poland. In consequence, Roma are brought from the outside or periphery of Polish social sciences to its core.

The study looked at international migration of Polish Roma from perspective of social anthropology with elements of social history. Since that area has never been systematically studied, the main aim was to fill this scholarly gap both in migration and Romani studies as well as to contextualize these migrations as part of overall international mobility from Poland post-1989. The gap in scholarship is particularly surprising since European scholars in the last decade produced an array of studies of migration of Roma within the EU with a notable silence on Roma from Poland. We aimed therefore to construct a picture of Polish Roma migration from selected localities since 1989 and capture similarities and differences between various groups of Roma under study as well as between them and their non-Roma (Gadjo) neighbours. Inevitably the research questions were broad, further specified during fieldwork. We were then focusing on issues traditionally explored in migration research such as: when and why did Roma begin to migrate? Are the reasons the same as non-Roma inhabitants of these towns? How migrations impact Roma communities in terms of shifts and changes in their identity, perception of the outside world and Roma culture?

At the same time we aimed at looking into the other end of migration process and chose Great Britain - where according to very few publications on the issue (Acton and 
Ingmire 20I2; Staniewicz 20II) Roma from Poland move since mid-9os (apart from other destinations, such as Ireland, Germany or Canada). We aimed also at analysing what is the impact of living in Britain on Roma culture, tradition, family relationship but also what can be said about their relationship with other groups they encounter during their migration trajectory - other groups of Polish Roma, Roma from other countries and other ethnic minorities.

Broadly speaking the study aimed at conceptualizing Roma as a transnational community which over long period of time has dealt with various structural and political factors such as collapse of the Berlin Wall, European integration, post EU enlargements intensification of intra-EU mobility. The aim was to determine how these impact on Roma communities, their life strategies and perceptions of the world. In this case, the concept of transnationalism is understood as a multi-layered "double orientation" of immigrants (Vertovec 2004, 970) resulting from the fact that communities, groups, families and individual lives span more than one nation states (Glick Shiller $e t$ al. 2004). A more precise and empirically viable concept of translocal connection is suggested and used by Anne White in her studies on migration from Poland (2OII, 20I4), pointing to the fact that migrants through their lives connect two specific localities, towns, villages rather than abstract nation-states. In this report both concepts are used depending on what aspect of life strategies of respondents needs to be emphasized.

Our key arguments in this article stem from the broad aim to link two abovementioned so far separate fields of Polish scholarship. The findings of our research point first, to the fact that Roma migrations from Poland are not categorically different and "exotic" linked with their alleged nomadic past, but are an integral and socially connected part of history of migrations from Poland on local and national level, determined by same processes of structural forces rendering people to seek opportunities abroad in the context of communist system in Poland as well as post 1989 political and economic transformations. Second, the article argues for a more careful and nuanced approach to Polish Roma identity seen in relational terms. Our study has demonstrated how crucial and important is for Polish Roma their connection to Poland - on social, personal, cultural and economic level. Third, our article calls for a need to a more ethically informed research with the Roma whose Polish identity needs to be recognized in its own right, in particular in migratory context. This means also few policy recommendations that we offer at the end of the article.

\section{FIELD SITES AND FIELDWORK}

Fieldwork was placed in broadly taken transnational social fields, understood here as transnationally or translocaly woven social networks between people living in two or more nation states who are linked through family or friendship connections with 
one locality in country of origin in Poland and Great Britain. It involved five locations: Czarna Góra, Kraków-Nowa Huta, Mława, London and Southend on Sea, in Essex and corresponded with taking into account two of the largest groups of the Polish Roma - Polska Roma (Mława) and Bergitka (Czarna Góra, Nowa Huta) - and what was known about destination localities from few publications about the issue (Acton and Ingmire 20I2; Staniewicz 2OII). The choice of Mława in addition was related to a significant analysis of Roma community there in the aftermath of the anti-Roma riots in 1991 (Giza-Poleszczuk and Poleszczuk 200I).

In line with any research involving transnational migrants we aimed at meeting and talking to members of families living in two countries. Overall we managed to capture lives of migrants at several stages of their transnational migration trajectories in all locations involved, but in addition, due to instances of inter-group intermarriages we managed to interview also people from the Chaładytka group and also Roma from towns like Krosno, Szczecin or the Lower Silesia region. This proved to be very beneficial enabling to some extent to extrapolate some findings from the locations in question to other places were Roma in Poland seem to undergo similar processes.

Research was conducted using a range of ethnographic methods - participant observations, non-structured interviews, group interviews, spending long periods of time with families involved in research, living in their proximity, participation in family events or rituals (like christening or funeral) and public community rituals (like the commemoration of Roma genocide by the Nazis ${ }^{2}$, or yearly pilgrimage in Limanowa ${ }^{3}$ ), diners, parties or music concerts. Given the transnational dimension of our study, it fitted a popular in migration studies method of multi-sited ethnography (Marcus, 1995) also used among the Roma (cf. Grill 20II). This methodological approach aims at tracing people, ideas, norms, practices through space and time and to map their interconnectedness, interdependence and meaning for individuals and groups. In migration research, typically it involves ethnographic observations and interviews carried out at all stages of migration chain, with people who are mobile, non-mobile, migrants, returnees, second generation and/or independent observers. Our fieldwork was continuous without a clear end and throughout our study we maintained constant contact with several key respondents with whom we shared information, gossip, opinions and family news. With these people we carried out repeated interviews which allowed us to constantly keep track of dynamic developments happening in front of our eyes, which we account in this report (in particular when it comes to intergroup

2 International Romani Caravan of Memory [Międzynarodowy Tabor Pamięci] is organized since 1996 r. by the Muzeum Okręgowe w Tarnowie i Kulturalno-Społeczne Stowarzyszenie Romów w Tarnowie: http://romopedia.pl/index.php?title=Mi\%C4\%99dzynarodowy_Tabor_Pami\%C4\%99ci_ Rom\%C3\%B3w, access: 20.10 .2018 .

3 Pilgrimage in Limanowa is organized since 30 years by Rev. Stanisław Opocki, Krajowy Duszpasterz Romów: https://tarnow.gosc.pl/doc/41926IO.Taborem-do-Matki, access: 20.IO.20I8. 
relations or religious conversions). In total we interviewed 80 people, although we have met and talked to many more. On top of these, we also carried out twelve expert interviews with a selection of people who due to their work or engagement with Roma had a specific insight helping us to understand processes at hand. These were for example: a local priest, former diplomat, expert on Roma issues, artist, journalist, member of Jehovah Witness congregation, local government official, or NGOs members. An archival search was also conducted at the Polish Ministry of Foreign Affairs and at the unique collection of Polish newspapers articles kept at the Ethnographic Museum in Tarnów. Social media are very popular among Roma of all ages, so its content was constantly monitored and observed.

Roma historical experience makes them sometimes suspicious of attempts to gather information by the Gadjo (non-Roma). In the past, this information was often used against them, to further oppressive state policies, surveillance practices of the police or racialized practices of identification, which in case of Nazi polices was used for genocidal purposes. The scale of refusal to our request for meetings and interviewing did not surprise us. We aimed at maximizing the participatory principle of our ethnography, where it was the respondent's decision over the course and content of the interview, which was inevitably unstructured and spontaneously sometimes evolving into discussion with the whole family over the kitchen table. Our participatory principle stems also from mixed Roma-Gadjo research team often making our discussions over data interpretations dialogical debates over meanings of Polish, Roma, and European identity in contemporary society. In this context, we hope that our project was the case of (still rare according to many Roma and Gadjo) what Roma may call khetanes Gadzie Romenca-cooperation between Roma and Gadjo. The principle ethical driver behind our research was to conduct it with maximum sensibility and the principle of not causing harm to our respondents in any way and with full respect of their worldview.

\section{BROAD SOCIAL AND HISTORICAL CONTEXT OF POLISH ROMA MIGRATIONS}

The constraints on international mobility during communist period concerned all citizens, Roma included, and as many other Poles at the time, they engaged in various strategies aimed at overcoming these restrictions. In Roma case however, the issue that distinguishes them from overall population was the forced sedentarization and "productivisation" of Roma nomadic populations, put into law in 1952, but implemented during the so called "settlement action" in 1964, which marks the end of nomadism of Roma groups that still maintained this form of livelihood (Drużyńska 2015; Mirga 1998; Mirga and Mróz 1994). In theory, this concerned nomadic groups, but in practice also impacted on those who lead a settled life. The so called "productivisation" offered employment in various new industries, which was also attractive 
for non-nomadic Roma, which lead to considerable internal migration from their traditional settlements in the Carpathian region, to Nowa Huta (near Kraków) or Lower Silesia (Golonka-Czajkowska 2013; Kapralski 2016).

For the nomadic groups, the tightening of communist state's surveillance, was a stimuli to look beyond Polish borders, as noted by Ignacy-Marek Kaminski, in his study of Roma emigration (more precisely, a group of Kelderasha families) to Sweden in the late 1970s (1980). Informally however, the communist state sometimes actively supported emigration of Polish Roma populations. In Dariusz Stola's history of international mobility from communist Poland, in the context of emigration of Germans from Poland in the 1970s, he notes that:

\footnotetext{
"With the restrictions in place, emigration was encouraged when it came to politically or socially unwanted individuals. In Katowice area the communists were getting rid of them to such extent that in 1974, a well informed colleague of Mieczysław Rakowski [a well know journalist, later one of last Prime Minister of communist Poland - authors] was telling him that 'there are almost no Gypsies (we sent them already 2 thousands)"” (Stola 20I0, 239).
}

As emigration of Polish Jews or Germans had political undertones, in case of Roma the readiness to give them "one way passports" was dictated by the local communist authorities' policy of getting rid of "socially cumbersome elements". This was the authorities' reaction to anti-Roma riots in Oświęcim in autumn 198I (Kapralski 2016; Mirga 1998), where in order to pacify the local population, around roo local Roma were offered a "one way passport" (wilczy bilet) to Sweden. The Swedish authorities on the other hand were also aware of what is happening and in fact this is what made them reintroduce visa restrictions:

"[Polish government - authors] wants to use the liberal visa rules to turn our country into a 'dumping' ground for people who for one reason or the other are seen as cumbersome in Poland. It may be about the Roma, as it happened recently" ${ }^{\text {. }}$.

The relative liberalization of mobility restrictions in the last years of the communist regime, meant that more and more Polish citizens - Roma included - began to move. As the report of the Union of Polish Roma notes (2012), end of 1980s and early I990s are the time of intensification of migration of Roma, mainly to Germany, Holland and Sweden. On a broader macrosocial level, international migration of Polish Roma was determined by political shifts that have impacted the entire region in the aftermath of the collapse of the Berlin Wall and communist system. As many scholars note, the

4 Ministry of Foreign Affairs, Department for Western and Northern Europe: Sweden [Ministerstwo Spraw Zagranicznych, Departament Europy Zach. i Płn: Szwecja]: This a translated exchange between Swedish minister O. Ullsten and an MP C. Bildt regarding the introduction of visa regime between Poland and Sweden; dated 6.04.1982. 
subsequent economic and political transformations have disproportionally hit the Roma populations (Stewart 1997, 2013) - they were the first to lose their jobs, to be subject of social welfare cuts and first to suffer the consequences of growing animosity of their neighbours, including raising racism and violence, also in Polish case (Bartosz 2004 [1994]; Giza-Poleszczuk and Poleszczuk 200I; Kapralski 20I6).

Both our respondents narratives and accounts, media reports and government communications, paint a very similar picture of migration of Roma starting in early ' 90 s to Germany and then, in mid '9os, shifting to Great Britain. In most of cases Roma used the asylum application system, mainly due to raising instances of racism and threats of violence (Talewicz-Kwiatkowska 2019, 44).

As mentioned, Germany was the main destination country in early ' $90 s$. where Roma usually applied for political asylum or had an irregular status, which sometimes lasted for many years prior to 1989 (Joskovicz 2016). Polish Ministry of Foreign Affairs archives point to the high number of people with irregular status, but without specifying whether these are people whose asylum claims have been rejected or are they economic migrants. For German authorities, the main problem was to determine their citizenship, necessary step to implement the readmission procedure, which was one of the main shifts in migration policy of newly reunified Germany.

It is precisely at that time, Roma from Poland began to alter their migration strategies from Germany to Great Britain where they most often claimed political asylum. Already in 1995 the Polish General Consul is being informed by the British about the "abuse" of asylum application system by Polish citizens, who are identified by Polish diplomats as Roma ${ }^{5}$. Successively Britain tighten its asylum procedures, while Poland joined the list of so-called safe countries. The number of applications falls the following year, but in 1998 it grows substantially, which again causes diplomatic tensions - with real prospects of reintroducing visas for Polish citizens.

Our experts recalling that period remember that during the bilateral talks of Polish and British officials on various levels, Roma are presented as "the problem" ${ }^{6}$, casting a shadow on ongoing negotiations about Polish membership in the EU. It is perfectly illustrated in the wording of the letter by Tony Blair in September 1999 to the Polish PM Jerzy Buzek, where he points that more than thousand Roma plus dependants has applied for asylum:

5 Ministry of Foreign Affiars, Department for Europe I, Great Britain: Embassy of the Republic of Poland, Political report for 1995 [Ministerstwo Spraw Zagranicznych, Departament Europy, Wielka Brytania: Ambasada Rzeczypospolitej Polskiej, Raport polityczny za rok 1995].

6 In the internal correspondence, prior to meeting the British, Polish officials are explicitly advised not to raise the subject of "Gypsy issue" on their own, only to react when it is raised by the Brits. 
"I am sure you find it as frustrating as I do that we should have to face this problem". Interestingly, he then points that I5O thousand Poles visit this country each year, the vast majority as genuine tourists, students, or on business" and they are "welcomed warmly".

Similar letter has been sent in 2002 to then PM Leszek Miller and also his Czech counterpart (Sobotka 2003, II3). In both, Blair emphasizes that Roma migrations seem to be well organized, thus it is necessary to work with Roma community leaders in the country to convey the message that applying for asylum is unlikely to succeed. Table I, demonstrates the dynamics of asylum applications from Polish citizens during years 199I-2004. The numbers relate to adults, without dependent children and are collected on the basis of citizenship of the claimant. This means that in the pool of claimants there are non-Roma Polish citizens, who claim asylum either on a different basis, or were "passing" for Roma, a part of diverse strategies of navigating the mobility and employment restrictions by Polish migrants (Garapich, 20I6).

Table I. Asylum application by Polish citizens in Germany and Great Britain I99I-2004 ${ }^{7}$

\begin{tabular}{|l|r|r|r|r|r|r|r|r|r|r|r|r|r|r|}
\hline Year & I991 & $\mathbf{1 9 9 2}$ & $\mathbf{1 9 9 3}$ & $\mathbf{1 9 9 4}$ & $\mathbf{1 9 9 5}$ & $\mathbf{1 9 9 6}$ & $\mathbf{1 9 9 7}$ & $\mathbf{1 9 9 8}$ & $\mathbf{1 9 9 9}$ & $\mathbf{2 0 0 0}$ & $\mathbf{2 0 0 1}$ & $\mathbf{2 0 0 2}$ & $\mathbf{2 0 0 3}$ & $\mathbf{2 0 0 4}$ \\
\hline $\begin{array}{l}\text { Great } \\
\text { Britain }\end{array}$ & 20 & 90 & $\mathrm{I} 55$ & 360 & I210 & 900 & 565 & I585 & I860 & I0I5 & 630 & 990 & I22 & $2 \mathrm{I}$ \\
\hline Germany & $\begin{array}{r}\mathrm{No} \\
\text { data }\end{array}$ & $\begin{array}{r}\mathrm{No} \\
\text { data }\end{array}$ & $\begin{array}{r}\mathrm{No} \\
\text { data }\end{array}$ & $\begin{array}{r}\mathrm{No} \\
\text { data }^{8}\end{array}$ & 200 & 190 & $2 \mathrm{IO}$ & 49 & 42 & 260 & I85 & 66 & 44 & 24 \\
\hline
\end{tabular}

As stated, majority of our Roma respondents in England share a similar migration trajectory - going to Germany in early 90, then coming back to Poland, and then moving to Great Britain. The regularity of that route shows the importance of social networks in these processes. At the same time, it must be stressed that this route, seems to be first tested by Polska Roma group, then disseminated to Bergitka Roma group (see section below for more details).

7 Own estimates using:

I) Asylum Statistics United Kingdom 1999, Jo Woodbridge, Di Burgum, Tina Haath, I7/oo, 12 Oct 2000,

2) Asylum Statistics United Kingdom 200o. David Matz, Rachel Hill, Tina Heath, 25 September 2001 I7/OI,

3) Refugees and Others of Concern to UNHCR 1998 Statistical Overview, Geneva,

4) Refugees and Others of Concern to UNHCR 1999 Statistical Overview, Geneva, July 2000,

5) Data for 2000-2004 from Great Britain and Germany: UNHCR Population Statistics Reference Database (access: 21.08.2018).

8 Despite lack of statistical data for that period, it is safe to assume that the figure was substantial, in particular in the early 90 s. 
Poland's accession to the EU in 2004 is the last structural shift affecting Roma mobility, however with a mixed impact depending on the locality and Roma group in question. From our findings it is clear, that after 2004, migration becomes more accessible and possible for those who were not able or could not make that move earlier. In the mass movement of Polish citizens after 2004, Roma have "disappeared" and are not a subject of any special interest nor concern for Polish authorities. Not that they are invisible, however, as according to our informants, some local governments directly involved in Roma issues treat their emigration as a positive outcome that will solve the problem of socially "unwanted elements".

The notable disproportion between the numbers involved and reaction of the governments having hallmarks of a moral panic (more in Clark and Campbell, 2000) needs to be noted. Crucially these are the migrating Roma who are seen as a security threat, their migration pathologized en masse as a "problem" and example of "abuse", and not the hundreds of thousands Polish citizens who enter the UK on false premises as tourists and work without permits (or sometimes pretend to be Roma, see Garapich 20I6).

\section{MICROHISTORY OF POLISH ROMA MIGRATIONS - MŁAWA, NOWA HUTA AND CZARNA GÓRA}

As in cases of other immigrant groups, the history of Polish Roma migrations bring forward hierarchies and divisions within that category. The sedentarization policy of communist regime has made some Roma to look beyond state borders, and living on the road for generations facilitated keeping in touch with various members of the extended kinship networks scattered across the region. It also put a premium on knowing the routes, finding information and implementing various strategies of dealing with mobility restrictions - which has been showed in Kaminski's (1980) account of a spectacular route of several families of Kelderasha in mid I970s., from Poland to Sweden (via Balkans and Italy). "People of tabor are more entrepreneurial" - as one of our experts said, meaning mainly an ability to navigate hostile mobility regimes restricting migrations. This refers mainly to Polska Roma group, and this stereotype is often reproduced by Bergitka Roma group who often point to vast transnational family connections Polska Roma has. How these networks operate in practice, is illustrated by the case of Mława, the town where part of our ethnographic study took place.

Roma in that town come from Polska Roma, with the subgroup self-referring term of Pluniaki; they lead nomadic lives until late 196os. They have engaged in intensive migrations to Germany from early 1980s, due to social networks established in Germany much earlier, we know of at least few cases of Roma from Mława who settled in Germany in the r96os. These international contacts were a source of significant economic status and social mobility due to engagement in used car dealership, which 
at the times of chronic shortages was a source of considerable wealth but also political influence in town. But not everyone had access to migratory social capital hence not everyone benefited from that lucrative trade. Our respondents frequently note the economic disparity within the local Roma community.

In 1991, the town become the site of infamous anti-Roma riots (Mirga 1997). Subsequent diagnosis of underlying roots of the riots show that migration driven accumulation of capital by Roma, their display of wealth and influence, along with the sudden impoverishment of local Gadjo coupled with the widespread crisis of legitimacy of power in the aftermath of collapse of communism lead to outburst of violence (see Giza-Poleszczuk and Poleszczuk 200I; Kapralski 2016). As noted by scholars, but also emphasized often by our respondents, the main focus of the attack were the wealthy households of Roma, not the barracks where the poorer families lived.

The Mława anti-Roma riots have been the accelerator of international migrations. This and other cases of riots and ethnic violence helped to justify asylum claims abroad, first in Sweden, then Germany and at the end in Great Britain. During that time, according to our interviewees as well as literature (Horton and Grayson 2008, 9) the largest outflux of Roma from Mława took place. However, it has to be noted that post-riot migrations have simply increased in frequency within an existing migration culture, so have broaden the strategy of Roma in which they were engaged in since at least a decade. Interestingly, some of our respondents have come back, sometimes few years after the riots. These early returns were mainly linked with the property they have left, but also relative lower economic status of the returnees. It seems the wealthier families had more motivations and resources to leave and settle abroad. Logically, Roma from lower end of social strata in Mława had less incentives and resources to leave permanently.

Polish accession to the EU and subsequent opening of the labour markets have been a crucial macrostructural determinant in migrations for Roma in Mława, as this time they encompassed everyone regardless of their economic status. Great Britain again becomes the main popular destination due to lack of transition periods for employment but also relatively straightforward system of social support in terms of schooling and housing, which was then used as the basis for bringing other members of the family. Today, these migrations between Mława and England (but also Ireland) are mixed in nature - some members of the same household live abroad, others circulate, others remain in Mława engaging in occasional transnational care or trips abroad.

Not all migration projects were successful and some families clearly have difficulties at meetings ends, and the money earned is usually spend on consumable good, a car or flat improvements. In that sense, post-accession migrations of Roma do not differ from migrations of their Gadjo neighbours. Some migration projects are marked by unpredictability, open-endedness and transnational ways of working and living with the future in form of retirement in Poland (Eade et al. 2006; Grabowska et al. 2017; 
White 20I4). Commenting on the younger generations approach, one of our elderly respondents for example says:

"...they have their flats here... got it ready, but won't leave it... they got it ready, earn there, come over the summer, stay a month or two and then again go there...."

But regardless of migration strategies, the long established migration culture and modernity driven macrostructural factors, mean that Roma community in Mława changes significantly. Young Roma are often confronted with diverse lifestyles and possibilities in Poland as well as abroad that may be contradictory to what their families and elders expect from them. Better off families with family connections abroad had more means and motivations to leave Mława early on, the less wealthy families chose a more transnational strategy of engagement between their town and England or Ireland. Strong family bonds of course still matter, and sometimes Roma reunite to keep the extended family together - for example during our fieldwork a daughter has returned after 20 years of living abroad. Some families engage in well known in scholarship among Polish migrants practices of transnational care (Barglowski $e t$ al. 2015; Wagner et al. 2016; White 20II), where usually grandmothers take care of their grandchildren while their parents work abroad. Those that remain or who returned often express strong sense of local patriotism. Mława is seen by them as a safe, known world without risk associated with losing local connections due to migrating, but also due to the safety net of property or state help. As one respondent told us, it is a place "I can go out in the evening and meet people I know", as opposed to the sense of anonymity and solitude experienced abroad, outside the closely knit Roma community.

In the context of Mława's bad reputation among Polish Roma, this emotional attachment is significant. It relates not only to Roma respondents' understanding of local history, but is a way of articulation ones' local roots and the status of being an integral part of town's landscape - we were often reminded, that despite the fact that in general Mława anti-gypsy riots cast a shadow over Roma-Gadjo relations, personally, they have experienced friendship and neighbourly care from their Gadjo co-habitants.

Despite all this, in the view of local experts, and some or our Roma respondents, the Roma community in Mława due to migration and aging is in decline. From more than 300 people (roughly 70 families) at the beginning of 1990 os. (Giza-Poleszczuk and Poleszczuk 200I), the community numbers now around 20-30 families (according to local wójt, the leader of Roma community) or Ioo individuals according to the city authorities ${ }^{9}$. At the same time our interviews and participant observation indicate that

9 Supreme Audit Office, post-audit note, 20I4: P/I4/II9 - Public administration activities for the protection of the rights of the Roma minority in Poland [Najwyższa Izba Kontroli, Wystąpienie pokontrolne, 20I4 r.: P/I4/II9 - Działania administracji publicznej na rzecz ochrony praw mniejszości romskiej w Polsce]. 
this is a transnational community with each family having strong family links with their kin in England, Germany, Canada or Ireland. Some of them still maintain strong links with the town. Traditionally, every All Saints Day on I $^{\text {st }}$ of November, Roma from Mława gather to pay their respect at the cemetery, and then to meet in a larger gathering for a dinner. Our respondents noted however that every year less and less people take part in these gatherings. As one member of the elders told us: "These days we only have funerals, no weddings, nothing...”.

Tellingly, last year the local property market registered changes indicating further out-migrations of local Roma. According to estate agents, some of the grand houses Roma built in the I980s during the time when Roma were prospering due to used car dealership, have been put on sale for the first time, and an increasing number of private flats owned by local Roma are rented to immigrant labour force - from Ukraine or China. This shows that some families begin to cut ties with the town. It is difficult to generalize on the whole country, but we also spoke to Roma from other towns in Poland that underwent a similar process of depopulation due to migration movements which began in the 1980s, resulting in social decline of local Roma life.

The second group among which the study was carried out were Bergitka Roma (called also Mountain or Carpathian Roma), a group originally living in Southern Poland, due to post-war internal mobility living also in Nowa Huta, Silesia with small communities in the North West. The ethnographic research was carried out in two locations - a rural settlement of Czarna Góra in Spisz region, and an urban, industrial suburb of Kraków, Nowa Huta. Unlike Polska Roma group, Bergitka Roma were a population leading a sedentary life previously mainly employed as blacksmiths and musicians, since 1950s. increasingly employed also in industries (Kapralski 2016; Mirga and Mróz 1994).

Besides incidental and sporadic individual migrations, Roma from Czarna Góra did not engage in international migrations in 1980s or 1990s. Few exceptions where some migrated to Britain or temporarily to Sweden were the results of intermarriages with Gadjo, or incidental contacts with foreigners and did not resulted in establishing a migration chains stimulating further outflows. It was Poland's accession to the EU that has had the biggest impact on that community. According to our respondents many families decided to use the opportunity of opening the British labour market to move to the United Kingdom. Our observations and interviews indicate that almost every family in that village (roughly around 25 families) have participated in these migrations to some extent - they have family members living in England, plan to leave soon, or have recently returned. Respondents' accounts indicate that just after 2004 migrations had hugely depopulated the settlement, whole families were leaving together. Table 2 is a compilation of official data and our own observations and interviews, indicating the scale of outflows: 
Table 2. Estimates for the number of Roma in Czarna Góra and Nowa Huta ${ }^{10}$

\begin{tabular}{|l|c|c|c|}
\hline & I990s. & Post-2004 accession period & 2017-2018 \\
\hline Czarna Góra & 250 & 70 & 100 \\
\hline Nowa Huta & 3000 & 2000 & 1800 \\
\hline
\end{tabular}

The threshold of 2004 for development of migration networks points toward an important finding of our study relating to role of ethnic boundary in migration networks. During our research and interviews we did not encounter any case of Roma from Czarna Góra, or nearby Zakopane and Podhale region who would tap into traditional and very extensive transnational networks of local Gadjo, who developed a distinct migration culture (mainly to Chicago) since the end of $19^{\text {th }}$ century (Pilch 1984; Walaszek 2007). Some respondents were surprised by the very idea, as in their worldview it was obvious that as a result of social and economic marginalisation, local migration capital which helps the Gadjo to engage in migration for at least five generations, were not shared with the Roma.

Low level of economic capital, qualifications and social capital of Roma from Czarna Góra, meant that it was the 2004 and opening of labour markets stimulated their international mobility. To some extent, the stabilisation of migratory status of their kin (e.g. from Nowa Huta, see below) already in Britain, played a role in their decision making, as some could use their presence and assistance during first steps while abroad. Certainly the post 2004 migrations, affecting every family in the village have contributed to established transnational networks helping people moving back and forth.

The interviews with returning migrants however, have brought forward a slightly different assessment of these migration episodes, as they are often talked about in terms of loss, mistake and emotional stress. They are seen as a difficult dilemma of being confronted with economic improvement on one hand but tensions from family separation and lack sense of security on the other. And similarly to Roma from Mława, the returnees are keen to emphasize their close connection to the local space. This was clearly linked in the interviews

IO Own estimates based on:

I. 200I-2003 Pilot Program for the Roma community in Malopolska Voivodship (http://mniejszosci. narodowe.mswia.gov.pl/mne/romowie/program-na-rzecz-spole/pilotazowy-program-rza/672I, Trescpilotazowego-programu-rzadowego-na-rzecz-spolecznosci-romskiej-w-wojewodzt.html), access: 20.10.2019

2. Program for the Roma Community in Poland 2004-2013: (http://mniejszosci.narodowe.mswia.gov.pl/ mne/romowie/program-na-rzecz-spole/program-na-rzecz-spole/tresc-programu-na-rzec/6670,TrescProgramu.html), access: 20.10.2019

3. Integration Program for the Roma Community in Poland 20I4-2020: (http://mniejszosci.narodowe. mswia.gov.pl/mne/romowie/program-integracji-spol/8303,Program-integracji-spolecznosci-romskiejw-Polsce-na-lata-2014-2020.html), access: 20.10.2019

4. Information from local Roma organisations. 
with a sense of culture shock felt by some of our respondents who are confronted with the complexity of large urban centres in Britain. But it also indicates that for Roma - as for many other groups maintaining close family bonds - migrations are a potentially disruptive situation, putting pressure on family ties and sense of security provided by familiar space of local Roma community. "The community is here" - as one of the returnee told us. This means that for some, migrations can lead to economic advancement, but at the same time they may also lead to the loss of status within Roma family, due to being outside the local stratification and status order. A similar point is made by Jan Grill (2012), whose research shows how gendered status of Roma men may change when abroad, and as a result may end up in prioritizing status over economic prosperity.

Our third field site, Nowa Huta district in Krakow, provides yet another, slightly different migration history of Polish Roma. Inhabited mainly by Bergitka Roma group who moved there in 1950s and 6os. to work around the steel factories, international mobility began also in the I990s., unsurprisingly with the collapse of large state owned industries due to socio-economic transition. Similarly to Polska Roma group, Bergitka Roma from Nowa Huta began to move to Germany mainly asking for political asylum.

Our research indicates clearly that the connections with Polska Roma were vital for establishing these migratory routes - these connections helped to plan ahead, get information how to interact with authorities, and how to settle, find jobs and assistance. The key role for establishing these networks was played by people with double group affiliation - usually men from Bergitka married into Polska Roma families. From various independent sources we were able to identify these "migration brokers" (Lindquist $e t a l$. 20I2; Xiang and Lindquist 20I4). These crucial actors on migration scene, were responsible for dissemination of migration strategies and organisation of travel on one side and on the other were tapping into international connections provided by Polska Roma group. These persons were actively involved in planning of migrations of many families from Nowa Huta (termed "przerzut" - meaning transfer, shift), both to Germany in early 1990 s and to Great Britain later on, following the pattern described in previous section. The scale of these activities and the fact that they connected different Roma groups, points to level of sophistication in planning which also was noted by the authorities.

The scale of migration from early I990s. means that Poland's accession to the EU did not have a similar dramatic impact on outflows as in the case of Czarna Góra. Nevertheless, as in the case of Mława migrations also contributed to significant depopulation of Roma from that town and their visibility - the well known, Nowa Huta "Roma block" on Osiedle ${ }^{11}$ Willowe (Golonka-Czajkowska, 20I3) isn't "Roma" anymore (table 2 above indicates the scale of that process).

Unlike the case of Mława however, it cannot be said that Roma community in Nowa Huta is in decline. There are numerous annual concerts there, several active 
Roma associations, Roma educational assistants are employed in local schools and day care centres, there are a number of social and cultural projects carried out. In addition, several Roma families from Romania settled in the town, opening another chapter of Roma presence in Poland. In that sense, despite large scale emigrations, Nowa Huta maintains its status of the "capital" of Bergitka Roma.

\section{TRADITION AND INTERGROUP RELATIONS}

One of our key findings, is the fact that international migrations have put different Roma groups in relative closer contact. Previously, Polska Roma and Bergitka Roma were isolated from each other in Poland geographically, but also socially, the later regarded by the former as having "lower status". Broadly they knew about each other's existence as evidenced by various terms used to refer to other Roma, sustaining also a specific hierarchy of groups (Ficowski 1965; Mróz and Mirga 200I). Social and political shifts in Poland after the collapse of socialism and subsequent emergence of Roma associations, sometimes linking all Roma groups (Grzymała-Kazłowski 20I5), led Roma activists to seek a common political ground in their relations with the Gadjo and began a more open and formalized struggle against discrimination, racism and economic deprivation. But these contacts were confined mainly to ethnic leaders. As noted by Agnieszka Kowarska, until fairly recently members of Polska Roma group regarded Bergitka Roma as "impure" and were of a view that contacts with them needed to be limited and marriages discouraged (Kowarska 20I0, 6). In our fieldwork, we encountered numerous instances of that internal hierarchization still important for some members of Polska Roma.

For the first time in Polish Roma studies we can claim that these contacts are becoming increasingly numerous, resulting in mutual partnerships, family links but also tensions and conflicts, which leads to important changes in the cultural lives of Polish Roma. It is clear that migrations were a key factor in that process. This is not only our observation from the field, but a widely shared view of most of our respondents - two groups come into contact more and more often abroad which as a result leads to more intergroup marriages and interactions.

On broader level the reasons behind this process lie in structural factors but also the collective characteristic of Roma migrations strategies in general - the fact that in general, Roma migrate in family groups (Matras 2013, 24) - this time linked with the process of settlement. Sometimes it lead to more organized and structured form of cooperation, as in the case of establishing of one of the most active and known Roma lead organisations in the UK, the Roma Support Group ${ }^{12}$, established with the help

Roma Support Group: http://romasupportgroup.org.uk/, access: 20.IO.20I8. 
of British academics, human rights activists and people engaged in supporting asylum seekers. Describing the circumstances of that organisation's creation, Acton and Ingmire (2012) note the important role Roma from Poland - mainly from Polska Roma but also Lovari and Kelderasha - played. Today members of Bergitka Roma are also active there and in that sense we can talk of a similar process going on as in Poland, where new Roma identity emerges, bridging, negotiating and sometimes contesting previous distinctions, group differences and hierarchies, in particular when they interact with the authorities that are not well tuned to the complexities of Roma identities. For many Roma who were not engaged in transnational ethnic mobilisation movement, this intensification of group interaction is a novelty. This isn't to say that old divisions disappear, they are still important dimension for most of our respondents' identities. We met members of Polska Roma who do not have any contacts with Bergitka Roma and vice versa. However, it is clear that Roma from Mława had little chance of meeting a member of Bergitka in their town, or Bergitka to meet a member of Polska Roma in Czarna Góra. In London or Southend this probability highly increases, a fact that what we directly observed during various rituals and events during our fieldwork.

One of the outcomes of more frequent inter-group relations and greater number of mixed marriages in particular, is the need to negotiate certain Roma traditions and customs understood differently by different groups, especially in relation to the status of women, gender roles and sources of authority in conflict resolution. For example, among many women from Bergitka Roma group we spoke to, there is a prevalent view that some of their kin who dressed "normally" in Poland (which usually meant wearing trousers or short skirts), become more "conservative" in England, dressing in a way more associated with women from Polska Roma group. In similar way a stricter division between male and female sphere, and pollution taboos are being raised as a point of negotiation between groups, in particular in the context of mixed marriages.

Interestingly, the dominant position of Polska Roma group is often negotiated and confirmed here. As it was often explained by our respondents, a female from Bergitka Roma marring into a Polska Roma family, is expected to adhere to their traditions and customs, but the same is also expected from a Bergitka Roma man who marries into Polska Roma - it is he, who needs to adapt. For some it is a proof of conservative and dominant position of Polska Roma (also financially, as often they are regarded as wealthier and more entrepreneurial). For others it is a proof of Roma traditions revival, in particular in a more tolerant and diverse context of British multicultural policies. There are however voices from Bergitka Roma group which sees this process as an attempt from the other group to assert its dominant position. Old hierarchies are being contested and questioned, with intermarriages as well as pan European Roma activism negotiating old stereotypes, since the latter rests on the assumption that Roma are a national/ethnic minority and internal differences are secondary to a common Roma identity. These discussions take place in Poland and in England simultaneously 
and can be heated and very emotional - which again points to the intensification of intergroup contacts due to migration. What differs in our view, is that discussions that were common among Roma activists, move to households that were previously indifferent to these processes.

This development can be challenging for both groups. On the one hand, some members of Bergitka Roma can feel dominated by Polska Roma, and concerned that in order to prove their Romaniness they are forced to take on traditions that were not common among them. On the other hand, for Polska Roma, inclusion of families not adhering to certain rules can be treated with concern, in particular when it comes to certain pollution taboos.

Crucially, more interactions and intermarriages, mean also more potential for dispute requiring a coherent and legitimate system of conflict resolution. Traditionally the top judiciary authority in Poland in custom Roma law, is the Sero Rom, the Roma king, currently living in Nowy Dwór Mazowiecki near Warsaw (Kowarska 20I3; Mirga and Mróz 1994). His rulings are generally accepted by all Roma groups in Poland, except Bergitka Roma who regards him as a member of the elders but not as ultimate authority (although there are also members of that group who do accept him as such). The dilemma thus is that in case of a dispute between members of Polska Roma and Bergitka Roma, the latter may refuse to accept Sero Rom's ruling, undermining his authority. The way out of that dilemma is to convince elders from Bergitka Roma to accept the king's authority, and we are witnessing an increasing number of attempts to do just that - for example during our fieldwork in winter 20I8, a prominent member of Polska Roma, came to Nowa Huta for a special gathering of local Roma (from Bergitka) to convince them (a part from discussions on many other things) to accept Sero Rom's authority.

Besides many other aspects and complexities of these Roma internal politics, it is important to stress that the discussions about that process are very lively in Roma households in Poland and England and are not solely connected to migrations but wider socio-political changes that Polish Roma undergo. Nevertheless we argue on the basis of our fieldwork, that migrations accelerate this process. This also points to an important dimension of Polish Roma connection with Poland. The ongoing political negotiation of Sero Rom's judicial authority sets Polish Roma apart from Roma from other countries and it may be interpreted not just as an attempt to unify diverse groups but a strategy aimed at keeping them linked through a common connection to Poland. In other words, the uniqueness of Sero Rom institution distinguishes Polish Roma from other Roma. It is also an element binding the Polish Roma groups is their more frequent interactions with Roma from other countries - in particular from Slovakia, Czech Republic and Romania.

Social media are of course a huge accelerator of this process. News about events, family rituals, conflicts, tensions travel fast across borders and it is quite common 
for Roma we met to live stream parties, christenings, weddings or other family events to their kin in other countries. These interaction very often involve Roma from diverse groups and one of the interesting linguistic outcomes of that process is the creation of a hybrid Polish-Roma-English idiom with which Roma communicate in writing, bridging linguistic divides. This in itself is an evidence of increased inter-group interactions, in particular among younger generation and how Roma in new context negotiate their complex and multi-layered identities in their own way, using own cultural resources and ideas linked to the importance of family, wider kinship group but also sentiments towards their locality or nation of origin. In the context of living in London these issues become important as they also negotiate diverse ways of being Roma, Polish but also British, Londoners and/or European.

\section{RELIGIOUS CONVERSION AND MIGRATIONS}

One of the aspects of our ethnographic study focused on religious conversions among Polish Roma and an interesting fact that Polish speaking Jehovah Witness congregations experience a growth of number of Roma among their ranks. This has been also noted by Acton and Ingmire (2012) without however an in-depth exploration of the dynamic behind this process, which in the context of popularity of Pentecostalism among Roma, is additionally intriguing.

It isn't easy to estimate the number of Polish Roma who are Jehovah Witnesses, although the testimonies as well as comments from non-believers Roma indicate that the trend is upwards and began with the migration flows in mid I99os. During our research, first Memorial of Christ's Death (a yearly ritual when Witnesses gather in great numbers across the world) has been organized specifically for Polish Roma and the sermon was delivered in Romani language, attracting around 250 people. According to Witnesses, there may be around one thousand Polish Roma who regularly come to Kingdom Halls, although it is difficult to verify that data.

As noted, majority of literature on Roma religiosity focuses on Pentecostalism, a hugely popular religious and ethnic revival movement across Europe (Acton 20I4; Roman 20I8; Podolinská 20I4). Some of the Polish Roma joined the Pentecostal church (cf. Nowicka 20I4), many others however, chose to join the other spectrum of Christianity. The fact that religious conversion to Jehovah Witness is a very frequent topic of conversations among Polish Roma we interacted with during our fieldwork (both believers and non-believers) indicates an important cultural shift and change as a result of migration and living in England. Our research covered three locations in Poland where we have not met any Roma who is a Witness, however, we were told of some Roma Witnesses living in various locations across Poland. From the narratives 
it seems that their conversion actually took place abroad, pointing to migration as the key factor in that process.

Why this is the case and what attracts Roma to the movement? We identify several factors behind this process linked. First, for our Roma respondents, the congregation is a safe space with a warm family atmosphere. According to come respondents, after their arrival to Britain the congregations became their "second home" where they felt included, safe and where linguistic and cultural proximity to non-Roma Polish co-believers helped to overcome feeling of stress related to the uncertainty of their immigration status, alienation due to living in a new country, or financial difficulties related to prohibition of employment. At some point of their settlement, practical aspects of being in a congregation also mattered, as it was a space where they could ask for information about accommodation, legal matters, employment. To some extent, the congregation acted as a similar social space to a Polish Catholic Church for Polish migrants which was a safe place not only to worship but to socialize. It seems the shared experience of exclusion from Polish society (Jehovah Witnesses being one of most disliked groups in Poland) brought these two groups together.

The social appeal of the congregation is also linked to a set of beliefs and practices that blend modernity with traditional beliefs. James Holden relates this to relationship with modernity that is stronger and deeper than it would seem on the surface from a millenarianist group. As he notes:

"On the surface, it would appear that Watch Tower theology represents a backlash against secular life, but closer investigation reveals that, in other respects, it is part of the very forces it condemns" (Holden 2002, 15).

This refers to business model of the evangelical work and a "desire for rationality" (Holden 2002, 65) visible in dress code, layout of Kingdom Halls, rejection of emotional responses during meetings, style of preaching and debating the issues of Watchtower during weekly meetings and the authoritarian nature of hierarchical structure of the movement - both at the level of organization and observable interactions between followers. Holden uses the Weberian notion of "technical reason" (Holden 2002, 8I) to argue that the Jehovah Witness have used characteristics of modernity to achieve appeal of followers along with social cohesion. Our Roma Jehovah Witnesses respondents directly engage with that discourse, arguing often that their religious path is an intellectual development and they are educating themselves through the Bible. The modernity driven message of advancement through knowledge and education is thus re-constructed in religious terms. Many Roma we spoke to see Bible readings sessions, coaching in public speaking, role-playing exercises aimed at teaching how to talk to evangelize people, etc. as education per se. We heard many stories of people actually learning to read and write as a result of becoming Witnesses. This exchange for example illustrates this perfectly: 
"[Respondent, female, 50 years:] So there are many cases like this, they are now more enlightened to learn. They don't take just facts... but want an answer: where is this written? Where the Bible comes from, how do you know it is authentic? And they compare facts... so they are more educated now you may say... and they finish schools... so I think they are not so backward anymore...

[Interviewer:] So they crave some knowledge right?

[Respondent:] Yes, they want knowledge and the younger generation too, thirty, forty years... and not all of them know how to read and write, and this is a great thing because they want to learn something new, right?"

The process of conversion is linked with their migratory routes and clearly went along family ties and extended kinship group networks, hence the growth of popularity of Watchtower congregations also stem from the abovementioned collective feature of Roma migration culture. There are, however, several more specific features that Roma themselves highlight in Watchtower dogma and practice as relatable to their Roma norms and traditions - mainly patriarchal gender roles, where male is the head of the household, emphasis on strict moral norms around sexuality, modesty in dress code, respect for the elders or the institution of exclusion from congregation which for Roma is seen as the equivalent of magerdo. Some also noted that Witnesses' general separation from the public, national affairs, in particular their resistance to national symbols and prohibition of their members to join the army and the police, a norm that is also found among some groups of Roma. Prohibition of blood transfusions also is relatable to some Roma taboos on blood.

Simultaneously however, the congregation setting, practice and dogma, offers sometimes a possibility of contestation and resistance to other elements of Roma culture that some Roma may find problematic or difficult. Being a Jehovah Witness allows sometimes to distance from family based ethical obligations and to refuse to participate in certain practices - for example christenings or Roma weddings. Sometimes it can also act as a tool of resistance of traditional gender roles. The best example is offered by one of our female respondents who was caught in a family dispute requiring a decision of the elderly to issue a binding ruling. The ruling required from her making an oath in public, something that not only Witnesses are forbidden to do, but since the opponent was male would put her in a disadvantageous position. Eventually she refused to make an oath citing her religious beliefs.

Our observations among Roma and non-Roma Witnesses in congregations in England, identify one more crucial factor behind the growth of popularity of Watchtower movement among that group. The last and very important piece of the puzzle, in the light of our findings, is the fact that the Polish members of the congregation during our visits were very eager to stress that the "Roma brothers" are an important part of the congregation. For them cultural and ethnic diversity in congregation is vital in order to challenge it and bridge it through the Jehovah Witness dogma. Roma presence is regarded as a proof that Polish members are following the path of the script - to 
overcome individual features and ethnic or national labels, to create a community of faith. Paradoxically then, migration and conversion has brought two different groups who live in Poland in isolation, together.

\section{RETURNS AND BREXIT}

Our respondents, especially returnees, talk also about migrations in negative terms - as risk, lack of networks of support and associated individualistic attitudes or dependency on family members abroad. Their return to Mława or Czarna Góra is then a return to known and safe environment, where social relations are embedded in traditional and established networks. "Roma are local patriots" - as one of our expert argues. Returnees we talked to, emphasize this bond with local space and nostalgia towards their community, since it was difficult to recreate it abroad. A return helps them realize the value of what community means and what it has on offer - sense of security, stability and position in local Roma community structure, which is at risk when abroad dependant on other branches of family. So an attachment to their locality of origin in thus strengthened by migration experience, an issue commonly observed in literature on migrants' returns, dilemmas of transnational living and care and nostalgia (Carling et al. 20I5; Erdal 20I4; Erdal and Oeppen 20I7; White 20II, 20I4). Some returnees may chose this sense of belonging and social status in their settlement over relative better economic position in England.

In other instances families are so dispersed that there is no one to return to, if they do not have any property (in case of social housing, families who left Poland lost rights to the communal housing) or they have been sold or rented. Coupled with the fact that children sometimes do not speak Polish, for many Roma a return is not an option, and their link with Poland and local community is being severed - as we seen in case of Mława. A general negative experience of schooling in Poland that parents refer to, makes then doubtful whether their returning children from England will be well catered for in Polish schools, in particular that they usually hold English schooling in high esteem. It should be stressed here, that Polish schools struggle also with other returning non-Roma Polish children with a migration experience. On the other hand, a new policy of child benefits (so called 500+) have been noted to be an additional incentive for some families to return.

The dilemmas our respondents articulate, do not differ from what we know from studies on migrants from Poland in general. They focus on problems with transnational care (Kordasiewicz et al. 2018), or the constant need to find an equilibrium between economic benefits of migrations with social and emotional costs of family separation and sense of alienation in a new environment. These similarities are also evident in the context of the Brexit referendum and its social and personal 
consequences, as for many EU citizens they generate heightened sense of uncertainty and unease, in particular bearing in mind the wave of anti-immigrant sentiment in the aftermath of the referendum. However, some scholars note that outcomes of Brexit may disproportionally affect Roma populations (Marley 2016) issue also raised by organisations such as Roma Support Group. There are various reasons for this overall, but from the narratives of our respondents, some made preparations securing their status - getting a resident certificate or applying and getting British citizenship. There are however cases that certainly will make that process difficult - due to lack of paper trail related to employment or past criminal convictions. Again, these are not specifically issues affecting Polish Roma, but overall relate to all EU citizens in Britain.

\section{DISCUSSION}

One of the main finding of this study is the realization that for more than a quarter of century Poland have been witnessing a largest - since the post-war emigration of Germans or Jews - exodus of its ethnic minority. What is more, this ethnic exodus went almost unnoticed. The small numbers involved should not offer an explanation for this situation, since we have seen the reaction of the Polish and British authorities and diplomatic tensions regarding the arrival of just a thousand families with children to Great Britain. The cases of Mława, Nowa Huta and Czarna Góra, at different times and in different ways show that in comparison to their non Roma neighbors, the Roma migrate to a much greater extent. The unprecedented scale of their emigration was highlighted earlier by some Roma organizations, but the study this article is based on is the first independent confirmation of this fact. As a result of migration, many Roma communities in Poland are in a demographic decline.

Another conclusion is that Roma migrations are not fundamentally and generally "different" or more "exotic" and are not an outcome of their culture, but are sociologically, economically and historically an integral part of the history of Polish society, the region or the city that they live in. At macro structural level, migrations of Polish Roma are on the one hand the effects of the liberalization of mobility regimes after 1989, on the other hand, they are related to the costs of the socio-economic transformation, when Polish citizens applied various livelihood strategies. Some people were involved in circular, informal migration. Others were leaving in groups asking for political asylum. In the context of the post-socialist trauma of great change (Nowicki 20I5, Sztompka 2000) and pauperization of society and ethnic tensions, the Roma, like other victims of systemic transformations (Rakowski 2009), were left mostly on their own but, most importantly, could rely on the supportive network of their own families, offering them economic and social capital necessary for survival. 
The same holds true for the Roma migrations after the EU enlargement in 2004, which for some communities was the beginning of large scale migrations. Their migration strategies, transnational ways of dealing with family issues and transnational care, upward social mobility abroad, as well as emotions related to migration, separation and returns do not differ from their non Roma neighbors. In some cases lower levels of education and a higher level of obligations resulting from family relationships impact on Roma migration choices, but generally speaking, one should refrain from exoticization of Roma migration. They do not result from the "nature" of the Roma, nor from the deterministically interpreted Roma culture stemming from their nomadic past. They are conditioned by the same macro-structural processes and the agency of social actors as migrations of their fellow non Roma citizens. Both cases of Czarna Góra and Mława shows it very well - the scale of migrations affected both these communities despite their very different mobility traditions. Obviously, certain Roma groups have had rich resources of migratory social capital, which allowed them to better navigate the new environment, understand the regulations or structural conditions. But other social groups in Poland were in possession of such capital too, which allowed them to effectively undertake migration and eventually settling abroad or circulating. Non-Roma inhabitants of Podhale, Podlasie, Opole used and sustained it in a similar way (Iglicka 2009; Jończy 20IO). The conceptualization of Roma migration as the result of their "urge to wander" abstracts them from the entirety of Polish society and is, in fact, a sociological and historical positioning of the Roma on the margins of the society.

As a result of migration, there is an unprecedented intensification of contacts between different Polish Roma groups, which is understandable by the logistical issues related to settling in, looking for friends and new relatives or expanding marriage opportunities. This results in a greater number of social spaces where groups so far isolated come into contact, intermarry, organize joint activities, etc. The consequences of this process are multi-faceted. On the one hand, we are witnessing a stronger identification with the conservative approach to the customs of the Polish Roma from the Bergitka Roma, a specific process of accepting Polska Roma traditions as their own. On the other hand, we witness a resistance from Bergitka Roma, especially when it comes to attempts to impose the superior authority of Sero Roma. Ultimately, it affects the emergence of a new dimension of the Roma identity, which exceeds the old intergroup divisions and hierarchies.

The next conclusion concerns the Polish identity of the Roma. Research findings regarding intergroup relations; the popularity of Jehovah's Witnesses movement; returns and emotional attachment to the place of origin - prove its significance in the identity construction process. Polish Roma, among whom we conducted ethnographic research - at least the majority, there are always some exceptions - identify (apart from being Roma) also as Poles, Polish citizens, people who, on the equal footing with the Gadjo are part of the Polish socio-cultural landscape which is a source of their sense of belonging and emotional ties. Like other migrants from Poland, they also feel an affinity with other 
Poles and the Polish culture in which they grew up. The attractiveness of Polish-speaking congregations of Jehovah Witness is indeed connected with their Polishness - other Poles go there, rituals are in Polish, and they feel accepted by other Poles as equals.

Similarly, the relations between Polska Roma and Bergitka today are intensified as a result of migration, because in both cases we are talking about groups of people connected to Poland who are abroad and are looking for a thread of commonality. We can even risk the statement that the Roma abroad, beyond the greater assertiveness regarding their own sense of identity as Roma, also become more aware Poles, aware of the value of the place they come from, Polish diversity and specificity. This is not a nationalist declarative patriotism of flags and marches but a kind of "grassroots", ordinary, everyday patriotism based on sentiment to food, landscape, childhood memories, customs, television, music, cultural idioms (such as the great respect and admiration for musicians like Don Vasyl or Edyta Górniak). As in the case of Polish non-Roma migrants, the settlement process and the emergence of the second generation will have significant effects on further cultural reproduction.

In this context it is important to note that during our study we met also numerous mixed Roma and Polish Gadjo couples which indicates that the boundary between what we, somewhat simplistically, understand as "Polish" or "Roma" communities are not distinct separate sets, but rather groups that may overlap in the context of the family but also other "Polish" social spaces such as Polish shops, concerts, work and - as in case of Jehovah Witnesses - religious congregations. In that sense we can view Polish Roma social lives in the UK as a modality of migration from Poland in general, adding to its diversity and homogeneity (Garapich 20I6; Kucharczyk 20I3; White 20II). The common language, sharing of similar cultural idioms, popular culture (in almost all households in England we visited, Polish TV is on), culinary tastes and links with specific localities in Poland, makes Polish Roma very close to other non-Roma Poles living in the UK. This picture is complex, as we also met some Gadjo who try to deny Polishness of Roma, stressing their "racial" difference. But when we asked our Roma respondents about their identity, we often got the response: "But I am Polish too!"

But if on the informal, family level these worlds sometimes overlap, it must be stressed that on formal and institutional level Polish Roma and Poles' social worlds in the UK are isolated and kept apart. We did not come across any Polish organisation (and there are a large number of them, see: Kucharczyk 2013) that would work with Roma or have Roma members, we are unaware of any cases of Roma children attending Polish Saturday schools and we did not hear about any activity towards that group from the Catholic Church. From our initial assessment, there is also little awareness of Polish Roma from the part of Polish consular offices. A small study among Polish civil society organisations in England, funded by the Polish Ministry of Foreign Affairs, found that the Polish Roma feel totally cut off from the interest and scope of Polish diaspora engagement policy, which the Ministry and the Polish Senate is engaged in (Garapich 2013, I54). 


\section{CONCLUSIONS AND ETHICAL DIMENSION OF RESEARCHING ROMA}

As we argue elsewhere (Fiałkowska et al. 2018) academic silence is never normatively innocent and the expulsion of Roma from mainstream migration studies discourse tells us something significant about contemporary Poland relations with diversity, immigration, and multiculturalism. In that sense, migrating Roma have certainly something interesting to say. On the basis of our study the first claim is that Polish Roma migratory experience needs to be treated as integral to the history of emigration from Poland in general. The history of Roma migration is as important sociologically and historically as are migrations of rural folk from pre I9I8 Galicia, Polish Jews in I968, forced emigration of WW2 soldiers or armies of economic migrants moving to the West during and after communist rule. Both on macroscale of structural conditions as well as microhistory of Polish towns and villages Roma live or lived in, these migrations need to be treated as interconnected with overall picture of mobility from the area.

In similar way, the presence of Polish Roma abroad, needs to be seen by both scholars as well as institutions as an integral part of the broadly taken Polish communities abroad. This means inclusion into the Polish diaspora engagement policy [polityka polonijna] aimed at engaging various stakeholders in preserving culture, traditions, language and historical understandings. The implicit omission of Polish Roma from overall diaspora engagement policy is an unfortunate sign of not only ethnically biased lens applied in that policy, but also explicit exclusion of Roma.

The importance of countering the essentialist myth of Roma as somewhat predestined to migrate, hence unable to put down roots in one place goes beyond academic debates but to the heart of local social policy. During our study we came across instances of local officials "hoping" for Roma to leave, taking with them "social problems" which in the views of the officials are associated with the Roma, not local discriminatory policy, racism, cuts in social welfare or lack of employment opportunities for Roma. The myth of Roma nomadic nature has actually negative social costs that need to be addressed and countered.

And last but not least, we need to make a note on ethics. Our research was able to offer anthropological insights described above due to participatory character of our ethnography but also basic attitudes of respect and equality between people engaged in dialogue and exchange of views, ideas and meanings. Unfortunately, Roma experiences with ethnographers and social scientists we came across point that this is not an iron ethical rule. In fact we heard stories of relations between ethnographers and Roma that sounded like instances of discredited $19^{\text {th }}$ century colonial anthropology with an "educated" member of enlightened "elites" treating Roma like subordinate subjects, invading their private, domestic space (for example recording without consent, taking picture of Roma houses interiors without consent etc.) or imposing a superior position. As ethnographers, but also Poles, Gadjo and Roma we call therefore our fellow 
ethnographers to involve Roma in all ethnographic research on participatory basis treating them with respect and as human beings, not - as many Roma say referring to practices of being observed by ethnographers "monkeys in a zoo".

\section{BIBLIOGRAPHY}

Act o n T. 20I4. New Religious Movements among Roma, Gypsies and Travellers: Placing Romani Pentecostalism in an Historical and Social Context. In D. Thurfjell and A. Marsch (eds.), Romani Pentecostalism. Gypsies and Charismatic Christianity. Frankfurt am Main: Peter Lang.

Acton T. and Ingmire S. 20I2. „I nikt nie rzuca w nie kamieniami”: romscy imigranci z Polski i ich wkład do polityki Romów/Cyganów/Wędrowców w Zjednoczonym Królestwie. Studia Romologica 5, 77-96.

Barglowski K., Krzyżowski Ł., Św ią tek P. (2015). Caregiving in Polish-German transnational social space: circulating narratives and intersecting heterogeneities. Population, Space and Place 2I(3), 257-269.

B a r tos z A. 2004 [1994]. Nie bój się Cygana. Pogranicze.

Carling J., Bolognani M., Erdal M.B., Ezzat R.T., Oeppen C., Pa asche E., Pett e r s e n V.S., S a g m o T.H. 20I5. Possibilities and realities of return migration. Peace Research Institute Oslo (PRIO).

Cla r k C. and Campbell E. 200o. 'Gypsy Invasion': A critical analysis of newspaper reaction to Czech and Slovak Romani asylum-seekers in Britain, 1997. Romani Studies IO(I), 23-47.

D r u̇̇y ńska J. 20I5. Ostatni tabor. Jak wtadza ludowa zakazata Cyganom wędrowania Poznań.

Eade J., Drinkwater S., Garapich M. (2006). Class and ethnicity - Polish migrants in London. Sociology 32, 259-275.

Erd al M. B. 20I4. This is my home. Pakistani and Polish Migrants' Return Considerations as Articulations About 'Home'. Comparative Migration Studies 2(3), 36I-383.

Erdal M. B. and Oeppen C. (eds.) 2017. Forced to return? Agency and the role of post-return mobility for psychosocial wellbeing among returnees to Afghanistan, Pakistan and Poland. In Z. Vathi and R. King, Return migration and psychosocial wellbeing: discourses, policy-making and outcomes for migrants and their families 18 . Taylor and Francis.

Fiałkowska K., Garapi ch M.P., Mirga-Wój tow i cz E. 20I8. Krytyczna analiza naukowej ciszy, czyli dlaczego Romowie migrują (z naszego pola widzenia). Kultura i Spoteczeństwo 2, 39-67.

Garapich M. 20I3. Między apatią a aktywnością - partycypacja polityczna migrantów z Polski w Wielkiej Brytanii. In J. Kucharczyk (ed.), Nic o nas bez nas. Partycypacja obywatelska Polaków $w$ Wielkiej Brytanii. Warszawa.

Ga rap ich M. P. 20I6. London's Polish Borders: Transnationalizing Class and Ethnicity among Polish Migrants in London. Stuttgart.

Giza-Poleszczuk A. and Poleszczuk J. 200I. Cyganie i Polacy w Mławie. Konflikt etniczny czy społeczny. In A. Jasińska-Kania (ed.), Trudne sąsiedztwa. Z socjologii konfliktów narodowościowych. Warszawa, 22I-247.

Golo n ka-Czajk ow ska M. 2013. Nowe miasto nowych ludzi 258. Kraków.

Grabowska I., Garapich P.M., Jaźwińska E., Radziwinowiczówna A. 2017. Migrants as Agents of Change. Social Remittances in an Enlarged European Union. Basingstoke.

Grabowska I. and Sarnowska J. 20I7. Transnarodowe wielostanowiskowe jakościowe badanie powtórzone w migrujących społecznościach lokalnych. Przegląd Socjologii Jakościowej 13(3), 6-28. 
Grill J. 20II. From street busking in Switzerland to meat factories in the UK: a comparative study of two Roma migration networks from Slovakia. In D. Kaneff and F. Pine (eds.), Global Connections and emerging inequalities in Europe: perspectives on poverty and transnational migration. Anthem Press, 77-IO2.

Grill J. 20I2. 'Going up to England': Exploring Mobilities among Roma from Eastern Slovakia. Journal of Ethnic and Migration Studies 38(8), I269-I287.

Grzymała-Kazłowski A. 20I5. Przywództwo i przedstawicielstwo. Studia Romologica 8(8), II5-I34.

Hold en A. 2002. Jehovah's Witnesses: portrait of a contemporary religious movement. Routledge.

Horton M. and Grays on J. 2008. Roma New Migrants: Local Research in the UKand European Contexts. A Conference Report. . Paper presented at The Research and Information Day.

I gl i c k a K. 2009. Bilans kosztów i korzyści najnowszej fali migracji zarobkowych z Polski oraz konsekwencje tego odpływu. Biuletyn RPO. Zeszyty Naukowe 66, 47-55.

Jo ń c zy R. 20Io. Migracje zagraniczne z obszarów wiejskich województwa opolskiego po akcesji Polski do Unii Europejskiej: wybrane aspekty ekonomiczne i demograficzne. Wrocław, Opole.

Joskovicz A. 20I6. Romani refugees and the postwar order. Journal of Contemporary History $5 \mathrm{I}(4)$, $760-787$.

K a m in s k i I.-M. 1980. The state of ambiguity: Studies of Gypsy refugees. Gothenburg.

Ka pralski S. 20I6. The Evolution of Anti-Gypsyism in Poland: From Ritual Scapegoat to Surrogate Victims to Racial Hate Speech? Polish Sociological Review I93, IOI.

Kordasiewicz A., Radziwinowiczówna A., Kloc-Nowak W. 20I8. Ethnomoralities of care in transnational families: care intentions as a missing link between norms and arrangements. Journal of Family Studies 24(I), 76-93.

Kow arska A. 20I3. Z badań nad przywództwem u polskich Romów. Studia Romologica 6(2013), I35-I54.

Kow a r ska A. J. 20I0. Stereotyp czy tradycja?: o etosie wędrowcy i wartościowaniu przestrzeni u polskich Romów. Związek Romów Polskich.

Ku ch a r c z y k J. 2013. Nic o nas bez nas: partycypacja obywatelska Polaków w Wielkiej Brytanii. Instytut Spraw Publicznych.

Lindquist J., Xiang B., Ye oh B.S. 20I2. Opening the black box of migration: Brokers, the organization of transnational mobility and the changing political economy in Asia. Pacific Affairs 85(I), 7-I9.

Marcus G. E. 1995. Ethnography in/of the world system: The emergence of multi-sited ethnography. Annual Review of Anthropology 24(I), 95-II7.

$\mathrm{M}$ a $\mathrm{t}$ a s Y. 20I3. Scholarship and the Politics of Romani Identity: Strategic and Conceptual Issues. RomIdent Working Papers. University of Manchester.

M a r le y M. 20I6. Roma communities and Brexit: Integrating and empowering Roma in the UK. London.

Mirga A. 1997. Romowie w historii najnowszej Polski. In Z. Kurcz (ed.), Mniejszości narodowe w Polsce. Wrocław.

Mirg a A. 1998. Romowie-proces kształtowania się podmiotowości politycznej. In P. Madajczyk (ed.), Mniejszości narodowe w Polsce: państwo i spoteczeństwo polskie a mniejszości narodowe w okresach przetomów politycznych (1944-1989). Warszawa.

Mirga A. and Mróz L. 1994. Cyganie: odmienność i nietolerancja. Wydawnictwo.

Nowicka E. 20I4. Konwersja religijna i konwersja kulturowa. Romowie zielonoświątkowcy w Szaflarach. Studia Humanistyczne AGH I3 (3), 165-183.

N ow i ck i T. 20I5. Badanie ku zmianie. Integracja i opór romskich rodzin wobec polityki wysiedleń. Pedagogika Spoteczna I, 207-243. 
Pilch A. (ed.) 1984. Emigracija z ziem polskich w czasach nowożytnych i najnowszych: (XVIII-XX w.). Warszawa.

Podolinská T. 20I4. Questioning the theory of deprivation: Pentecostal Roma in Slovakia. In D. Thurfell and A. Marsh (eds.), Romani Pentecostalism: Gypsies and Charismatic Christianity. Frankfurt am Main, 89-I09.

R a k ow ski T. 2009. Eowcy, zbieracze, praktycy niemocy: etnografia cztowieka zdegradowanego. Warszawa.

Rom a n R. B. 20I8. Religious Humanitarianism and Transnational Roma Missionary Work as DeConstructions of Migration. Roma Mobility, Beyond Migration. Intersections. East European Journal of Society and Politics 37.

S o b o tka E. 2003. Romani migration in the I990s: perspectives on dynamic, interpretation and policy. Romani Studies I3(2), 79-I2I.

St a niewicz T. 20Ir. Negotiating space and contesting boundaries: The case of Polish Roma and Polish migrants. Migration and adaptation as viewed via a social capital lens. Studia Migracyjne - Przeglad Polonijny 37(I, I39), 259-289.

S t e w a r t M. 1997. The time of the Gypsies. West View Press.

S t e w a r t M. 20I3. Roma and Gypsy "ethnicity" as a subject of anthropological inquiry. Annual Review of Anthropology 42, 415-432.

S tola D. 20I0. Kraj bez wyjścia?: migracje z Polski 1949-1989. Instytut Pamięci Narodowej, Komisja Ścigania Zbrodni przeciwko Narodowi Polskiemu.

S z t o m p ka P. 2000. Trauma wielkiej zmiany: spoteczne koszty transformacji. Instytut Studiów Politycznych PAN.

Talewicz-Kwiatkowska J. 2019. Persecution and Prejudice Against Roma People in Poland after World War II. The Polish Review 64(2), 37-45.

Ver tove c S. 2004. Migrant Transnationalism and Modes of Transformation. International Migration Review 38(3), 970-I00I.

Wagne r M., Fiałkowska K., Pi echowska M., Łukowski W. 20I6. Niemiecki proszek do prania i polnische Wirtschaft: polscy robotnicy sezonowi w Niemczech: obserwacje etnograficzne. Warszawa.

Wa las ze k A. 2007. Migracje Europejczyków I650-I9I4. Kraków.

Wh i te A. 20Ir. Polish families and migration since EU accession. Policy Press.

W h i t e A. 20I4. Polish Return and Double Return Migration. Europe-Asia Studies 66(I), 25-49 [doi: I0.1080/09668136.2013.85502I].

$\mathrm{Xiang}$ B. and Lind qu is t J. 20I4. Migration infrastructure. International Migration Review 48(I), I22-I48.

Związek Romów Polskich. 20I2. Raport o sytuacji spoteczności romskiej w Polsce. Szczecinek. http://www. romowie.com/raport.pdf.

\section{Internet sources:}

International Romani Caravan of Memory [Międzynarodowy Tabor Pamięci]: http://romopedia.pl/index. php?title=Mi\%C4\%99dzynarodowy_Tabor_Pami\%C4\%99ci_Rom\%C3\%B3w

Roma Pilgrimage in Limanowa: https://tarnow.gosc.pl/doc/41926Io.Taborem-do-Matki

200I-2003 Pilot Program for the Roma community in Malopolska Voivodship: http://mniejszosci.narodowe.mswia.gov.pl/mne/romowie/program-na-rzecz-spole/pilotazowy-program-rza/672I, Trescpilotazowego-programu-rzadowego-na-rzecz-spolecznosci-romskiej-w-wojewodzt.html

Program for the Roma Community in Poland 2004-2013: http://mniejszosci.narodowe.mswia.gov.pl/mne/ romowie/program-na-rzecz-spole/program-na-rzecz-spole/tresc-programu-na-rzec/6670, TrescProgramu.html 
Integration Program for the Roma Community in Poland 20I4-2020: http://mniejszosci.narodowe.mswia. gov.pl/mne/romowie/program-integracji-spol/8303, Program-integracji-spolecznosci-romskiej-wPolsce-na-lata-20I4-2020.html

Roma Support Group: http://romasupportgroup.org.uk

\section{Authors' addresses:}

Kamila Fiałkowska PhD

Ośrodek Badań nad Migracjami UW

ul. Pasteura 7, 02-093 Warszawa, POLAND

e-mail: k.fialkowska@uw.edu.pl

ORCID 0000-0002-I473-9987

Michał P. Garapich PhD

Ośrodek Badań nad Migracjami UW

ul. Pasteura 7, 02-093 Warszawa, POLAND

e-mail:m.garapich@uw.edu.pl

ORCID 0000-0003-0248-6780

Elżbieta Mirga-Wójtowicz

Ośrodek Badań nad Migracjami UW

ul. Pasteura 7, 02-093 Warszawa, POLAND

or

Uniwersytet Pedagogiczny w Krakowie

ul. Podchorążych 2, 30-084 Kraków, POLAND

e-mail:emirga@interia.pl

ORCID 0000-0002-3215-7825 
